\title{
The limits of economic theories and models
}

\section{Hans VISSER \\ Vrije Universiteit Amsterdam, The Netherlands}

\begin{abstract}
:
Aim: This article was written out of a felt need to reflect on the relationship between economic theories and models on the one hand and the empirical world as we experience it on the other. The question is in particular whether it is possible for economic models and theories to say anything definitive about the world we live in.
\end{abstract}

Design/Research methods: The article relies on professional publications, both within the field of economics and outside of it.

Conclusions/findings: There is much reason for humility, economic models and theories have hardly anything definitive to say about the empirical world, and there is a need for a more varied menu of theories and models and for a listening ear for the needs and fears of the population at large. The best we can do is discussing competing and conflicting views in a polite way. However, this requires a Sprachethik that looks more and more like an endangered species.

Originality/value of the article: Recent developments concerning the reach of economic models and theories are related to earlier discussions and a way forward is sketched.

Keywords: Economic methodology, The role of economists, Teaching of economics, Paradigms / Worldviews

JEL: A11, A20, B41

Correspondence address: Hans VISSER, Professor Emeritus of Monetary Economics, Department of Economics, School of Business and Economics, Vrije Universiteit Amsterdam, The Netherlands. E-mail h.visser@vu.nl. Website: http://personal.vu..nl/h.visser.

Received: 14.09.2020, Revised: 24.11.2020, Accepted: 24.11.2020

doi: http://dx.doi.org/10.29015/cerem.887 


\section{Introduction}

This paper is born out of the realization that epistemological questions are easily neglected by economists, save for a bunch of specialists (the price of the extreme specialization of the field). As academics we work with theories and models, and with the help of these theories and models we try to say relevant things about the world we live in. Even if we are not epistemology experts and lack the language to analyse the subject matter in any depth we have to ask ourselves how our theories and models relate to the empirical world, and, as builders and/or users of those theories and models, also how we ourselves relate to the empirical world, how we see the empirical world, what our worldview is. The paper is an attempt to come to grips with such fundamental problems of scholarly activity.

For economists the question has assumed special urgency because there is a widespread feeling that they have let the world down recently. They generally did not see the 2008 financial crisis coming and in the wake of the crisis all kinds of unorthodox policies had to be applied to prevent the world economic system falling apart. These look like having been reasonably successful, but how much the perceived effects were due to the measures taken is far from clear. The covid-19 crisis again demands immediate action that leaves little time for reflection, we just have to act before large sections of the population are reduced to poverty and too many business firms have gone to the wall and we have no clear answer to the question how we should deal with the resulting rise in government debt, and how far we should go in letting it rise.

All this confronts us with the question: how relevant are our economic theories and our models for the problems the world wrestles with, and how relevant can they be? What are the limits of economic theories and models? In order to find an answer, I first clarify what I mean by the terms 'theory' and 'model'. Next, in Section 3 I take issue with the popular idea that economic models provide a simplified picture of the 'real' world. Section 4 then argues that models nonetheless can be useful if we accept an 'as if' methodology and pragmatism, while Section 5 sketches the limitations of formal models. Section 6 explores the relevance of one's paradigm, worldview or 'vision'. Section 7 returns to the question what we still can expect from our models and theories, given the limitations that have been discussed. 


\section{THE LIMITS OF ECONOMIC THEORIES AND MODELS}

Section 8 goes into the way any discourse among economists and between economists and the wider public could, or should, ideally be held, given the limitations of our professional activities; it is followed by some concluding remarks.

\section{What do we mean if we talk about theories and models?}

Economists work with models and develop theories. These terms are used in different senses, with none necessarily the only correct one (Goldfarb, Ratner 2008). It may be confusing, but there is nothing basically wrong with any given definition of the terms, if only a definition is given. I find it useful to define a model as a consistent set of variables and relationships between those variables that is used to study a class of phenomena (e.g., labour market dynamics, GDP fluctuations or balance-of-payments dynamics). These relationships can be expressed verbally, in mathematical form, i.e., in a set of equations, and often also in diagrammatic form.

Models in my use of the term are not synonymous with theories. Theories are attempts at explaining phenomena (say, unemployment, a financial crisis or a persistent balance-of-payments surplus). They may make use of models, but a model in itself does not explain real-world phenomena. What a model does, however, is provide a framework for theories. If we choose a model, we choose a set of variables assumed to be important and the kind of relationships that we expect to have good explanatory value. By choosing a model we may restrict the degrees of freedom for our theories. We choose a model that fits the kind of problems that we find important and the way we think those problems should be analysed. A model does not, however, per se determine our theory. Consider, for instance, a very simple, one-equation, model, the equation of exchange:

$$
M V \equiv P y
$$

where $M=$ the money supply, $V=$ the (income) velocity of money, $P=$ the price level and $y=$ real income. 
This is an identity. It doesn't say anything about causality. It can be seen as a model, not as a theory. It will only become a theory if we add causality, for instance: if we increase $\mathrm{M}, \mathrm{P}$ will increase more or less proportionally (the quantity theory). Or: if we increase $\mathrm{P}, \mathrm{M}$ will increase (endogenous money). A case can be made that both theories can be true, but not at the same time. It may depend on institutional arrangements or on policy choices. Those different theories, which purport to explain real-world phenomena, can be accommodated by this simple one-equation model. Note, however, that potentially interesting problems associated with changes in the price level or the money supply, in particular distributional effects, will slip below the radar if we rely exclusively on the equation of exchange. Formal models may function as blinkers.

\section{Are models a simplified image of the 'real' world?}

Economists will usually tell you that their models offer a simplified representation of the real world. That looks like a lazy man's methodology. Consider a basic Keynesian fix-price model for a closed economy:

$$
\begin{aligned}
& Y=Z(Y, i, T)+G(I S \text {-curve }) \\
& M s=\operatorname{Md}(Y, i)(L M \text {-curve })
\end{aligned}
$$

where $Y=$ national income, $i=$ rate of interest, $T=$ amount of taxes, $G=$ government expenditure, $M s=$ money supply, $M d=$ money demand, $Z=$ aggregate demand

Does this look like a simplified version of the 'real' world? If so, the 'real' world should look like a more complicated version of the model. Does it? Just look out of the window. To start with, in the world that we observe we do not discern the variables that figure in our models, such as consumption goods and investment goods. Instead, we may see a lady taking delivery of a large fridge for her delicatessen shop and a small one for her apartment one floor higher. The first one is denoted as an investment good, the second one as a consumption good. Far from 


\section{THE LIMITS OF ECONOMIC THEORIES AND MODELS}

giving a simplified image of the 'real' world, the model makes us categorise our empirical observations using categories that precede observation. Our model structures our look at the world and what we see there (for an exhaustive study of the role of models in economics see Morgan, Knuuttila 2008). If by 'real' world we mean something more profound, some reality beyond the empirical world as we see it, we put ourselves in the role of Plato's philosophers, who have escaped from the cave where the common people live as prisoners and have seen the real world in full sunlight, whereas the prisoners only see shadows on a screen (Plato 1968: 278ff, part VII, book VII). But if we pretend to have seen the light, how can we possibly be sure that what we find there we have not first put there ourselves?

The tension between the empirical, observable world and the world of economic models becomes even more glaring in Don Patinkin's once-famous Money, Interest, and Prices (Patinkin 1969). It is a work of great beauty and elegance which impresses with its meticulous analysis of general-equilibrium models with money that is, until it is realized that money in a timeless general-equilibrium model with perfect markets (or a sequence economy without learning or missing markets) is inessential, a term Frank Hahn used to denote the situation that no monetary variable need enter into the description, or determination, of that economy's equilibrium (Hahn 1973: 230). Money has no useful role in such worlds, they could perfectly function without money and modelers will have to use tricks such as a cash-inadvance requirement to justify the use of money. The futility of models where money is inessential is made clear by Patinkin's (1969: 75) attempt to "conceive of a barter economy as the limiting position of a money economy whose nominal quantity of money is made smaller and smaller." Patinkin had to admit that a fall in the nominal quantity of money will reduce the price level and thus leave the real quantity of money unaffected in equilibrium. Still, "This drawback notwithstanding, there does not seem to be any other meaningful way of comparing the respective equilibrium positions of a barter and money economy." Such an approach is of no use in studying real-world problems. Only this should not be read as a call to dump general-equilibrium models. Patinkin also made it clear that the real side of the economy and the monetary side cannot exist independently alongside each other. Neutrality of money in a comparative-statics analysis (meaning that the real side of 
the economy is not affected by changes in the money supply, which only affects the price level but not price ratios) still requires a real-balance effect and/or an interestrate effect for changes in the monetary sector to affect prices. That means that excess-demand functions need to contain monetary arguments. Building on this model it has been spelled out what far-reaching assumptions have to be made to retain neutrality of money in a comparative-statics sense (Aschheim, Hsieh 1969; Visser 1971). This means that monetary policy will have distribution effects, and that is of practical importance. What we need thus is more diversity of models and approaches, not a farewell to the 'hard' tradition.

\section{4. 'As if' methodology and pragmatism}

Economic models and theories do not give a simplified representation of the 'real' world. In order to do that, we should first know what the 'real' world looks like, and that is beyond our faculties. Our observations are limited and different people see different things. What we see is essentially chaotic: we see people going from their homes to schools, hospitals, offices and factories and back, we see trucks transporting goods, ships from all continents calling at our harbours and so forth and so on. How to make sense of it all? What we do in formulating economic models and theories is not represent the 'real' world in a simplified picture, but attempt to get a mental grip on the world. It is the construction of a mental picture of how the world, or at least that part or aspect of the real world that forms our research object, might function. In the words of McCloskey "We humans must deal in fictions of our own making. Whether or not they correspond to God's Own Universe is something we cannot know" (McCloskey 1994a: 195). This does not mean that anything goes: a model must be logically consistent and we are often able to test whether the results we find when manipulating the model are rejected or not in empirical research. The model, or the theory dressed in the garb of the model, thus may be refuted. But we'll see that this is often not sufficient to get a definitive answer to the question whether a theory should be rejected or not. Nevertheless, the exercise can be useful. 


\section{THE LIMITS OF ECONOMIC THEORIES AND MODELS}

To give an example: we could draw up a model of a car driver deciding whether or not to overtake the car before her. We may use mathematical formulas and make the driver in the model make her decisions on the basis of her own speed, the speed of the car before her, the distance between her and oncoming traffic and the speed of oncoming traffic. The model may turn out to be successful in tracking and forecasting drivers' behaviour, but nobody will believe that drivers really perform any numerical calculations. When using the model we do as if drivers behave according to the model. This way of using models is accordingly known as as if methodology. It owes its formulation to Milton Friedman (1953), who also called it the methodology of positive economics. With this 'as if' methodology, it does not come as a surprise that economic models make liberal use of metaphors: liquidity, circulation of money (cf blood circulation); in economic models there's a lot flowing around, with various degrees of viscosity.

Friedman's 'methodology of positive economics' is often seen as a form of instrumentalism (Frazer, Boland 1983; Webb 1987). Instrumentalism is "the position that scientific theories are calculating devices that facilitate the organization and prediction of statements about observations. It is the statements about observations that are true or false. Theories are merely 'useful' or 'not useful'" (Losee 2001: 257). Not surprisingly, some observers see close links with John Dewey's pragmatism (Wible 1987), which Dewey himself dubbed instrumentalism (Wible, Sedgley 1999: 176). Dewey was not interested in the question whether a theory was 'true' in any sense, but in the question whether it could solve a problem, that is, whether it was a useful theory (Dewey 1938; Suhr 2005). Dewey focuses on "the function of consequences as necessary tests of the validity of propositions, provided these consequences are operationally instituted and are such as to resolve the specific problem evoking the operations" (Dewey 1938: iv).

Economists and philosophers of science strongly disagree on the value of instrumentalism. One view, exemplified by Webb, states that Friedman's approach may lead to nonsensical views being taken seriously, as long as their implications are not too obviously at odds with the results of empirical research. But perhaps that's the poverty of economics, we may have nothing better to offer, except that if there are competing theories or models we might find parts where they have 
diverging implications and we can test which one performs best. Webb is too negative, in my view. And arguably this was a non-issue for Friedman, because he was not so much interested in the truth claims of a theory but in the predictive powers of a theory. The purpose of a theory is "prediction for purposes of testing and evaluating alternative policies" (Frazer, Boland 1983: 129). The choice of a theory is decided by its usefulness, that is its success in predicting future effects of a policy. As Frazer and Boland (1983), following Boland (1979), argue, Friedman's position is free of logical error, he was simply focusing on another issue than most philosophers of science. Still, when there are competing theories and one performs better than others, it does not mean that the others can be relegated to the dust bin, as we will see in Section 6. An another question is that models and theories are not only used for policy purposes or for solving real-life problems. We also use them to interpret history or to try to make sense of present-day situations and developments. But let us first focus on some limitations of formal models.

\section{Limitations of formal models}

Relying predominantly on formal models has its costs. Models, especially mathematical ones, restrict our degrees of freedom. They exclude variables that do not lend themselves easily to mathematical formulation. For instance, on the level of individual agents elements like love and hate can easily be introduced in a formal analysis by adding other people's well-being in our utility function, with a positive coefficient in the case of love and a negative one in the case of hate. However, in general-equilibrium models this hardly possible, and my mathematical-economics colleagues tell me it is simply impossible for negative interrelationships, hate in this case. In macroeconomic models such feelings, and feelings in general (such as attitude to immigration), are left out completely. Other obviously important forces that have an impact on the variables we are usually interested in, such as growth, income and wealth distribution and environmental degradation, find no place in economic models either. Think cultural, institutional and political factors that stimulate or hinder productive activities (trust, social capital), and even the central 


\section{THE LIMITS OF ECONOMIC THEORIES AND MODELS}

figure of the entrepreneur. Perhaps even worse, the impact of growth and the pursuit of growth on a variety of cultural, institutional and political variables finds no place in the models either. Economic theories of course need not restrict themselves exclusively to the use of formal models and the importance of entrepreneurs and institutions is readily accepted in theories of economic growth and development and in research by economic historians. However, economic policy relies heavily on mathematical models and elements that do not fit these models are always in danger of getting neglected. And it is not only the field of economics that suffers from the dominance of 'hard' science which leads to the neglect of important issues. Benjamin Cohen notes that it is no different in the field of political science, in particular International Political Economy. Unexciting but technically competent work focused on narrow individual relationships has driven out "interpretive theory or grand visions of history and society" (Cohen 2010: 888).

Another point is that the study of societies, of human behaviour, differs from the study of, say, astronomy or cosmology in the sense that our activities as observers may change the systems we observe. Human society is not a given system outside us, we are part of it, which adds to the difficulty, or is another cause of the impossibility, of constructing a 'true' model. When economic surveys or forecasts are published, people will react and change the system, especially if their reaction functions change over time, that is, are unpredictable. Furthermore, we live in a world of fundamental uncertainty, we cannot have any idea of how various variables will develop in the future and what variables will become important that are now not, and the other way round. This fundamental uncertainty was already recognized by Frank Knight (Knight 1921) and by John Maynard Keynes in his Treatise on Probability (1921) and in the General Theory (Keynes 1936). "Fundamental uncertainty would imply that no matter how hard we try, no economic model would ever come close enough to the true underlying fabric of the economy, simply because no such true fabric exists." (Müller-Kademann 2018: 59, see also Dosi, Roventini 2019).

Now these latest limitations to models also apply to the theories that make use of the models, though they need not impair the value of the theory. They only limit the value of forecasts, which at best can be of the 'if, then' variety. However, 
the use of models and theories is not restricted to making forecasts. They are also used to interpret the past, and in that use the limitations may be easier to live with. If the models applied in alternative theories would make conflicting predictions of the results of historical events, Friedman's instrumentalism might be of some use, as in Friedman and Schwartz's A Monetary History of the United States, 1867-1960 (1963). But not more than some use, as we will see now - and for interpreting present situations and developments it looks like it's of no use whatsoever.

\section{Paradigm, vision, worldview}

As was observed at the end of Section 3, our model structures our look at the world and what we see, and it is only logical that our choice of model in its turn is closely connected to our worldview, the way we look at the world. This worldview precedes our empirical explorations and includes the aspects we think important and the questions we want to be answered. Different authors use different terms for this view that precedes scholarly inquiry. Worldview does not seem to differ much from what Schumpeter in his History of Economic Analysis (it is nigh on impossible to leave out the epithet 'monumental') called 'vision'. Schumpeter argues that 'in order to be able to posit to ourselves any problems at all, we should first have to visualize a distinct set of coherent phenomena as a worth-while object of our analytic efforts. In other words, analytic effort is of necessity preceded by a preanalytic cognitive act that supplies the raw material for the analytic effort" (Schumpeter 1967: 41). "Analytic effort starts when we have conceived our vision of the set of phenomena that caught our interest. [...] and this vision is ideological almost by definition. It embodies the picture of things as we see them, and wherever there is any possible motive for wishing to see them in a given rather than another light, the way in which we see things can hardly be distinguished from the way in which we wish to see them" (Schumpeter 1967: 42). ${ }^{1}$ I would agree if "the way in

\footnotetext{
${ }^{1}$ Interestingly, a similar idea formed the foundation of a peculiar branch of philosophy, the neoCalvinist philosophy of sphere-sovereignty developed by the Dutch Professor Herman Dooyeweerd (1894-1977) and still extensively studied and discussed in Calvinist academic groups all over the globe:
} 


\section{THE LIMITS OF ECONOMIC THEORIES AND MODELS}

which we wish to see them' not necessarily points to an outcome we would applaud, but could also be based, for instance, on a sense of impending disaster. As for the term 'paradigm', the Oxford English Dictionary defines it as "A conceptual or methodological model underlying the theories and practices of a science or discipline at a particular time; (hence) a generally accepted world view."2 The term was introduced into the philosophy of science by Thomas Kuhn for ideas maintained for longer periods by scholars in a field without being put to the test. It is similar to the 'hard core' of Imre Lakatos's 'research programmes' (Klant 1994).

In Lakatos's approach, a research programme is made up of methodological rules on the research paths to avoid (negative heuristic) and the research paths to pursue (positive heuristic) (Losee 2001: 203). The negative heuristic isolates a 'hard core' of propositions that are accepted by convention and which are not exposed to falsification. In economics one might perhaps think of the presupposition of a movement to equilibrium after a shock, or the belief that there is such a thing as equilibrium. The positive heuristic is "a strategy for constructing a series of theories in such a manner that shortcomings at any particular stage can be overcome" (Losee 2001: 204). This strategy will result in a 'protective belt' of auxiliary hypotheses around the hard core. Unlike the hard core, the auxiliary hypotheses can be subjected to empirical tests, and thus can be falsified or refuted, which is Karl Popper's criterion of the scientific status of a theory (Popper 1976: 37). Falsification is, however, not a reason to say farewell to a research programme, in Lakatos's view. It may lead to modifications of the protective belt of auxiliary hypotheses, in order to better fit the empirical measurements. This is not so say that any ad-hoc auxiliary hypothesis will do. Lakatos distinguishes between 'progressive problemshifts' and 'degenerating problem shifts'. If the adjustments in the protective belt results in theories that account for the successes of earlier theories, have a greater empirical content (explain more) than earlier theories and see some of their newly

\footnotetext{
"(philosophical) thought is never neutral and always needs to start from an Archimedean or transcendental point to grasp the meaningful totality of reality." (Hengstmengel 2012: 416).

2 The term 'paradigm' has become popular in the philosophy of science through Thomas Kuhn's book The Structure of Scientific Revolutions (University of Chicago Press, Chicago 1970). He created some confusion by using the term in the sense defined above, but also in a more narrow sense, defined by the Oxford English Dictionary as "a pattern or model, an exemplar; (also) a typical instance of something, an example" (see Losee 2001: 200-201).
} 
added content corroborated, the problem-shift is progressive (Losee 2001: 204-205). Refutation is not identical with rejection. A paradigm will be replaced by another paradigm if a scientific community decides that the new paradigm is able to explain phenomena that were anomalies within the old paradigm, and the more readily if the new paradigm leads to better quantitative precision (Losee 2001: 200).

How might this hard core - auxiliary hypotheses approach work out in the field of economics. Economic models often have a very high level of abstraction. They start from a number of premises, such as that welfare or utility for a consumer is an increasing function of the number or volume of goods and services they can lay their hands on, but with a negative second derivative, that is, marginal utility is falling; or that work is a disutility. These premises in their turn are based on the postulate of methodological individualism, which means that the focus is on the decisions of individual agents. Another hard-core element is, as noted above, the postulate of equilibrium. The models then proceed by developing full-fledged models and theories through deduction. The models and theories are axiomatic systems (Klant 1987: 19). One might say that the premises are the hard core in the sense of Lakatos, whereas the results of the deduction are open to empirical refutation, as for instance that the demand for a good is a negative function of its price. If that conclusion is refuted by empirical tests, the protective belt of auxiliary theories becomes active. The hard core itself often receives a protective shield against empirical tests and thus against refutation through the claim that it is immaterial whether the premises are from removed from the empirical world, on the contrary, it is propagated that it should be, as economics makes use of the as if methodology: the empirical world is too complicated to start with and we make use of metaphors. You cannot complain if metaphors do not stand empirical tests, that's inherent to metaphors. A theory can thus never be said to be 'true' in an absolute sense, only to be more scientific in the sense of Popper than other theories - and this the more so as the hard core is not subject to the test and thus not 'scientific' in Popper's terminology.

It may be noted that Popper made a sharp distinction between falsification and verification of a theory. Marxists for instance are able to explain just about everything that happens in the world and see everywhere verifications of Marxist theory (Popper 1976: 34-35). Those who do not see the same way suffer from a 


\section{THE LIMITS OF ECONOMIC THEORIES AND MODELS}

'false consciousness'. Verification provides very weak support for a theory and if any falsifiable proposition based on Marxist theory fails the empirical test, Marxism ranks lower as a scientific theory than theories that are not refuted.

It should be realized that implicit worldviews or visions are quite distinct from ideology-driven use of models that in themselves are free from that ideology. A glaring case is the glorification of GDP growth that can often be found in official publications. High GDP growth suits policymakers because it functions as a measure of their success and lands them high on international league tables. High growth also is a decisive factor in electoral success if it goes hand in hand with low unemployment. However, while there is a positive correlation between GDP and health and other welfare indicators (e.g., Jones, Klenow 2016), it does not follow from standard economic theory that maximizing GDP growth, even under some restrictions (limiting $\mathrm{CO}_{2}$ emissions, for instance), is optimal. A main element of standard economic theory as taught in the popular textbooks is the concept of opportunity costs: if you want more of A, chances are that you have to give up some of B. If you want more growth, it will usually cost you such things as leisure time, volunteer activities and environmental quality and it will bring more stress. Maximizing GDP growth will probably only be optimal when applying the utility functions of some politicians and planners.

\section{What can we expect from our models and theories}

Economic models and theories try to pinpoint the main variables that explain the value of other variables, but for conditional forecasts or ex post explanations to be useful it must first be assumed that the relationships between the various variables are more or less stable over time and secondly that the many variables that are assumed to have negligible or only weak influence and are therefore left out of the model more or less offset each other. If then a theory is refuted, that does not mean it is rejected. Additional hypotheses can be developed about for instance structural breaks in the relationships between variables or exogenous shocks, that is, a sudden non-negligible value of a variable outside the model used in the theory. With such 
additional hypotheses it is very difficult to definitely reject a theory, and it is quite possible for more than one theory explaining a phenomenon to exist side by side, unless or until falsifiable corollaries of competitive theories can be put to the test, or until a large majority of leading professionals decides which ones provide Lakatosian 'progressive problem-shifts' and which ones 'degenerating problem shifts'.

Seemingly 'scientific' methods, with impressive mathematical methods, thus provide no certainty, and in economics and other social sciences most likely less certainty than in physics, which can rely on a number of constants, such as the speed of light in vacuum and the Planck constant. This has particularly forcefully been argued by Deirdre McCloskey, who claimed for instance that "formal methods of reasoning have little to do with the belief widespread among economist that people engaged in mutually advantageous exchange should be left alone. Yes, you can draw a diagram about it; and if you don't like that you can employ a fixed point theorem about it. But the conviction is mainly political and ethical" (McCloskey 1999: 60-61). In Lakatosian terms, it belongs to the hard core.

McCloskey emphasizes that "all knowledge is rhetorical, an agreement among Us" (McCloskey 1999: 63). She presses home her conviction that science is mostly persuasion rather than demonstration and persuasion includes logic and fact but also metaphor and story, it is rhetoric (McCloskey 1994b). Models are the metaphors that professionals use to look at their field of study. This appears to be widely accepted, we all talk about 'narratives' and no longer about conclusive proofs, but the choice of narrative in economic policy all too often seems to lack logic (as in the case of the primacy of growth) - and textbooks still tell you that their models are a 'simplified representation of the real world'. Is all this talk of a narrative then only a fad? One wonders whether the great majority of economist realize that Kuhn and Lakatos announced what Hoksbergen (1994) calls the death of foundationalism. Foundationalism is "the notion that we can come to a true understanding of the world if our theories are logically based on some indubitable foundation"; however, "There are only narratives based on particular perspectives and viewpoints" (Hoksbergen 1994: 670). Whether all this should lead to a postmodern position that truth is completely subjective, is a moot point. The trouble with economics is that 


\section{THE LIMITS OF ECONOMIC THEORIES AND MODELS}

there are few causal relationships which can be as firmly supported by empirical evidence as, say, the causal relationship between smoking and lung cancer. It should be possible, though, to agree that though core models themselves cannot be disproved, at least models and theories derived from these models can be compared and that in some cases one offers a more convincing explanation or prediction than others. That prevents absolute subjectivity, or 'my opinion is as much worth as yours'. But it still requires professional groups that are able and willing to listen to each other and seriously discuss diverging views. This idea has been further elaborated by McCloskey and Klamer.

\section{Economic discourse}

Klamer and Meehan (1999) argue that knowledge is a variety of processes and each process is generated within a circle of practitioners, with its own rhetoric. McCloskey uses several descriptions of the concept of rhetoric. What she means can, according to Mäki, best be formulated as "Rhetoric is the use of arguments to persuade one's audience (and the study thereof)" (Mäki 1995: 1303). Such a rhetoric consists of metaphors, narratives (described by Klamer and Meehan (1999: 69) as "the employment of events and the characterization of individuals and groups"), and the selection of authority. If we want to convey a message, we need a strategy of persuasion, that is, a rhetoric, which, Klamer and McCloskey say, has four elements: facts, logic, metaphors (models), and stories (Klamer, McCloskey 1989: 140-141). Even if we try to persuade fellow-specialists we do not without stories.

What then if people start from different worldviews, how to prevent talking at cross-purposes? Klamer and McCloskey argue that in discussions with other professionals, who may disagree with us, we should apply the 'Maxim of Presumed Seriousness', that is, presume that others are as serious as we are, unless there is evidence to the contrary (Klamer, McCloskey 1989: 141). We have to follow 'conversational norms of civilisation', or what McCloskey, borrowing from Jürgen 
Habermas, calls Sprachethik. ${ }^{3}$ These norms are nothing special, they simply are: don't lie, pay attention, don't sneer, co-operate, don't shout, let other people talk, be open-minded, explain yourself when asked, don't resort to violence or conspiracy in aid of your ideas. (McCloskey 1985: 24; 1994a: 99).

These rules are fine for discussions among professionals, if they are really willing to listen to each other, but economists also have to deal with other people if they give policy advice or try to explain empirical developments. If they try to communicate with the help of formal models or theories with a high level of abstraction, they may convey the impression of great learning, but over the last few decades people tend to be less and less impressed by such showing-off. Unfortunately, the economic mainstream (measured by the kind of publications in the top-rated journals) has become more and more formal and mathematical and economists are thus more and more in danger of getting remote from the rough and tumble of economic life as people experience it - with honourable exceptions such as Joseph Stiglitz $(2013,2019,2020)$ and Thomas Piketty (2014) with their analyses of inequality. How can we as economist communicate with 'ordinary' people. How do we persuade them of the value of, say, theories of international trade that highlight the benefits of specialization, competition and Schumpeterian 'neue Kombinationen' ('new combinations'); and how can they persuade us of their concerns about loss of jobs or their fears of a shift from secure skilled jobs to insecure low-paid unskilled jobs?

McCloskey mentions an image which, she tells, is popular in sociology and brought into economics by Arjo Klamer, amongst others: the street floor, where you have to go if you want to know what it is like to be a member of a crowd, and the eighth floor, where you are better placed to make generalizations about the behaviour of the crowd as a whole (McCloskey 1999). On the street level you miss a wider perspective, but you feel the threats and the stress, and occupants of both levels can only persuade each other of the value of their analyses if they are willing to listen to each other.

\footnotetext{
${ }^{3}$ It would be too much of a digression to explore the relationship between McCloskey's use of the term and what Habermas meant. See on this Park, Kayatekin (2000).
} 


\section{THE LIMITS OF ECONOMIC THEORIES AND MODELS}

Klamer and Meehan distinguish between a circle of academic economist and a circle of 'everyday economists'. The academic economists may presumably be thought to occupy McCloskey's eighth floor, whereas the 'everyday economists' dwell on the street level. They are businessmen making decisions about buying and selling or expansion, and also politicians deciding on a policy. Perhaps we should include everybody else as well, all who have to make decisions about seeking, accepting or rejecting jobs, about spending and saving; and all who are affected by monetary policies, trade policies and migration.

Klamer and Meehan state that everyday economists are most likely to personalize the economy, they think in terms of right and wrong, of victories and defeats and of identities. Between these two circles is a third one, the circle of 'policy entrepreneurs', including academicians who venture too much outside academia to be taken serious on the eighth floor, and economic journalists. These policy entrepreneurs might be able to mediate between the other two circles. A problem Klamer and Meehan notice with academic economists is that they consider policymakers who do not subscribe to their theories and advice stupid. This does not help to bridge the gap between the eighth floor and the street level. Academic economists will have to realize that their rhetoric is impenetrable to others, otherwise they cannot well contribute to a solution of society's ills (note that McCloskey calls herself a pragmatist, McCloskey 1995). Of course, communication is a two- (or multi-)sided process and politicians all too often only 'listen' to academic economists if their studies support the politicians' policies or plans. Anyhow, the politicians communicate with a totally different rhetoric.

For conversations with the street level more is required than a decent 'Sprachethik'. Economists should seriously pay attention to the needs and fears of members of the public, and narratives about what is 'good for the economy' simply will not do if people feel job security and affordable health care and housing are sacrificed in the process. This will require a shift in the institutional setting of the economics profession. As has been forcefully argued by George Akerlof (2020), amongst others, professional advancement is to a great deal dependent on so-called 'hard' research work, heavily mathematical, and this tendency is self-reinforcing because those who rise to the professional top also are editors of the top-ranking 
journals and make the important hiring decisions. Akerlof fears that this goes at the cost of a bias against new ideas and results in overspecialization. It leads to a very narrow worldview and may have been a major cause of the fact that the leading economists did not see the financial crisis coming, not taking a rather 'soft' economist such as Hyman Minsky seriously. It was Minsky against DSGE (Dynamic Stochastic General Equilibrium models), and DSGE won. The mainstream had no place for the realization that people do not learn from the past and collectively delude themselves into thinking that 'this time is different' (the title of Carmen Reinhart and Kenneth Rogoff's (2009) seminal study of financial crises. After all, collective forgetfulness jars with the premise of rational expectations, so beloved by economists.

\section{Concluding remarks}

The time now seems ripe for a more diverse approach to economics, which does not glorify maths at the expense of 'soft' approaches and subjects. An excellent step in the right direction is the text by John Komlos, Foundations of Real-World Economics (Komlos 2019). He thinks students are led astray if they are fed a menu of rational economic agents and perfect competition and so on, without warnings of the abstractions made by the textbook models and the limitations of markets, along with the limitations of government. His text goes a long way to make students feel they study a subject that is close to the world and its problems as faced by real people, and not an abstract mathematical universe. At the least for undergraduate studies and policy discussions, it would be beneficial if we opt for relevance over rigour (Salanti 2014). ${ }^{4}$ As for reaching out to the street level, the publications by Joseph Stiglitz mentioned above come to mind.

What is needed is reasoning that leaves room for qualitative aspects and relationships that do not lend themselves easily to mathematic modelling. This is of course nothing new, think of Herbert Simon's idea of bounded rationality, with

\footnotetext{
4 "Rigor is a matter of being consistent with theoretical principles, while relevance has to do with the possibility of transferring conclusions or predictions obtained within the model to what actually happens in the external world." (Salanti 2014: 157).
} 


\section{THE LIMITS OF ECONOMIC THEORIES AND MODELS}

economic agents as 'satisficers' rather than optimisers (Simon 1955), or of Thorstein Veblen's theory of the leisure class and conspicuous consumption (Veblen 1918), which has the character of a scholarly essay rather than a study based on empirical fact-finding or rigorous deduction, just like John Kenneth Galbraith's studies of the power of near-monopolists (Galbraith 1963 [1952]) and of private consumption versus public services (Galbraith 1962 [1958]). They do not impress with advanced mathematics, but provide illuminating insight into the functioning of human society, possibly changing one's worldview (just what Benjamin Cohen is also missing in political science). Such ideas and theories, which tend to be relegated to footnotes or recommended, not required, reading, contribute much more to understanding how our world functions than for instance Don Patinkin's Money, Interest, and Prices mentioned above (Patinkin 1969).

An approach to economics that includes 'soft' analysis and research, along with Lakatos's distinction between 'progressive problem-shifts' and 'degenerating problem shifts' and also the pragmatists' focus on problem-solving would do much to improve the quality of conversation and prevent a post-modernist situation where everyone has their own truth. Final answers may not be found, but it should be possible to agree on what can be deemed acceptable theories or explanations and what not. We may for instance never be able to find a definitive answer to the question what exactly triggered the economic successes of the four Asian Tigers (Singapore, Hong Kong, South Korea and Taiwan) or what the relative roles of land reform and export policies in those successes were in the cases of South Korea and Taiwan, but the proposition of some people that these countries simply were lucky and North Korea, North Vietnam and, since the 1976 reunification, Vietnam before the economic liberalization measures starting in 1986 remained poor just because of bad luck (too much or too little rainfall, bad harvests) ${ }^{5}$ can be reasonably be rejected as a sore loser's argument. However, no polite exchange of arguments is proof against the strong forces that do not care a cuss for Sprachethik and scholarly expertise or are even hostile to it, proof against people who are $100 \%$ convinced of their own ironclad truth or are willing victims of complot theories. Perhaps we can soften their stance a bit by paying serious attention to their daily worries, descending

\footnotetext{
${ }^{5}$ This I heard some true believers in revolution argue in the early 1980s.
} 
from our lofty eighth floor to the street level. This will certainly not solve the problem that the willingness to listen to each other is a commodity which is in short supply, but we should never give up trying.

\section{References}

Aschheim J., Hsieh Ching-Yao (1969), Macroeconomics. Income and monetary theory, Merrill, Columbus, Ohio.

Boland L.A.(1979), A critique of Friedman's critics, “Journal of Economic Literature”, vol. 17 no. 2, pp. 503-522.

Cohen B.J. (2020), Are IPE journals becoming boring?, "International Studies Quarterly”, vol. 54 no. 3, pp. 887-891.

Dewey J. (1938), Logic. The theory of inquiry, Henry Holt and Company, New York.

Dosi G., Roventini A. (2019), More is different ... and complex! The case for agent-based macroeconomics, "Journal of Evolutionary Economics", vol. 29 no. 1, pp. 1-37.

Frazer W.J., Boland L.A. (1983), An essay on the foundation of Friedman's methodology, "American Economic Review", vol. 73 no. 1, pp. 129-144.

Friedman M. (1953), The methodology of positive economics, in: Essays in positive economics, University of Chicago Press, Chicago - London, pp. 3-43.

Friedman M., Schwartz A.J. (1963), A monetary history of the United States 1867-1960, Princeton University Press, Princeton.

Galbraith J.K. (1962 [1958]), The affluent society, Penguin Books, Harmondsworth - Middlesex.

Galbraith J.K. (1963 [1952]), American capitalism. The concept of countervailing power, revised edition, Harmondsworth, Middlesex.

Goldfarb R.S., Ratner J. (2008), "Theory” and "models": Terminology through the looking glass, "Econ Journal Watch", vol. 5 no. 1, pp. 91-108.

Hahn F.H. (1973), On the foundations of monetary theory, in: Essays in modern economics (the proceedings of the Annual Conference of the Association of University Teachers of Economics, Aberystwyth 1972), eds. Parkin M., Nobay A.R., Longman, London, pp. 230-242.

Hengstmengel J.W. (2012), Dooyeweerd's philosophy of economics, "Journal of Markets \& Morality", vol. 15 no. 2 , pp. $415-429$.

Hoksbergen R.(1994), Postmodernism and institutionalism. Toward a resolution of the debate on relativism, "Journal of Economic Issues", vol. 28 no. 3, pp. 679-714. 


\section{THE LIMITS OF ECONOMIC THEORIES AND MODELS}

Jones Ch.I., Klenow P.J. (2016), Beyond GDP? Welfare across countries and time, "American Economic Review”, vol. 106 no. 9, pp. 2426-2457.

Keynes J.M. (1936), The general theory of employment, interest and money, Macmillan, London.

Klamer A., McCloskey D. (1989), The rhetoric of disagreement, "Rethinking Marxism", vol. 2 no. 3, pp. 140-161, www.deirdremccloskey.org [04.12.2020].

Klamer A., Meehan J. (1999), The crowding out of academic economics. The case of NAFTA, in: What do economists know? New economics of knowledge, ed. Garnett Jr R.F., Routledge, London - New York, pp. 65-85.

Klant J.J. (1987), Filosofie van de economische wetenschappen, Martinus Nijhoff, Leiden.

Klant J.J. (1994), The nature of economic thought, Edward Elgar, Aldershot.

Komlos J. (2019), Foundations of real-world economics, 2nd ed., Routledge, New York - Abingdon.

Losee J. (2001), A historical introduction to the philosophy of science, 4th. Ed., Oxford University Press, Oxford.

Mäki U. (1995), Diagnosing McCloskey, “Journal of Economic Literature”, vol. 33 no. 3, pp. 1300-1318.

McCloskey D.N. (1994a), Knowledge and persuasion in economics, Cambridge University Press, Cambridge.

McCloskey D.N. (1994b), How economists persuade, "Journal of Economic Methodology", vol. 1 no. 1, pp. 15-32.

McCloskey D.N. (1995), Modern epistemology against analytic philosophy. A Reply to Mäki, "Journal of Economic Literature", vol. 33 no. 3, pp. 1319-1323.

McCloskey D. (1999), Jack, David, and Judith looking at me looking at them, in: What do economists know? New economics of knowledge, ed. Garnett Jr R.F., Routledge, London - New York, pp. 60-64.

Morgan M.S., Knuuttila Y.T. (2008), Models and modelling in economics, paper, in: (2012) Handbook of the philosophy of economics, ed. Mäki U., Elsevier/North-Holland, Amsterdam, http://ssrn.com/abstract=1499975 [04.12.2020].

Müller-Kademann Ch. (2018), The Lucas critique. A Lucas critique, "Economic Thought”, vol. 7 no. 2, pp. 54-62.

Park M.-S., Kayatekin S.A (2000), McCloskey, economics as conversation, and Sprachethik, "Cambridge Journal of Economics", vol. 24 no. 5, pp. 565-580.

Patinkin D. (1969 [1965]), Money, interest, and prices. An integration of monetary and value theory, 2nd. ed., Harper \& Row, New York.

Piketty T. (2014), Capital in the twenty-first century, transl. A. Goldhammer, The Belknap Press of Harvard University Press, Cambridge, MA - London. 
Plato (1968), The Republic, transl. and introduction H.D.P. Lee, Penguin, Harmondworth.

Popper K.R. ( 1976 [1972]), Conjectures and refutations. The growth of scientific knowledge, 4th ed., Routledge and Kegan Paul, London - Henley.

Reinhart C.M., Rogoff K. (2009), This time is different. Eight centuries of financial folly, Princeton University Press, Princeton, N.J.

Salanti A. (2014), Rigor versus relevance in economic theory. A plea for a different methodological perspective, "History of Political Economy", vol. 46 no.1, pp. 149-166.

Schumpeter J.A. (1967 [1954]), History of economic analysis, ed. from manuscript by E. Boody Schumpeter, George Allen \& Unwin, London.

Simon H.A. (1955), A behavioral model of rational choice, "The Quarterly Journal of Economics", vol. 69 no. 1, pp. 99-118.

Stiglitz J.E. (2013), The price of inequality, Penguin, London.

Stiglitz J.E. (2019), People, power and profits. Progressive capitalism for an age of discontent, Allen Lane, London.

Stiglitz J.E. (2020), Conquering the great divide, “Finance \& Development”, vol. 57 no.3, pp. 17-19.

Suhr M.(2005), John Dewey zur Einführung, Junius Verlag, Hamburg.

Veblen T. (1918 [1899]), The theory of the leisure class, new edition, B.W. Heubsch, New York 1918, https://oll.libertyfund.org/titles/veblen-the-theory-of-the-leisure-class-an-economic-study-ofinstitutions [07.07.2020].

Visser H.(1971), Neutraal geld, een overzicht, “De Economist”, vol. 119 no. 4, pp. 393-439.

Webb J. (1987), Is Friedman's methodological instrumentalism a special case of Dewey's instrumental philosophy? A comment on Wible, “Journal of Economic Issues", vol. 21 no. 1, pp. 393-429.

Wible J.R. (1987), Criticism and the validity of the special-case interpretation of Friedman's essay. Reply to Webb, "Journal of Economic Issues", vol. 21 no. 1, pp. 430-440.

Wible J.R., Sedgley II N.H. (1999), The role of econometrics in the neoclassical research program, in: What do economists know? New economics of knowledge, ed. Garnett Jr R.F., Routledge, London - New York, pp. 169-189. 